\title{
Human Capital and Regional Entry of Firms
}

\author{
Elisabet Berglund \\ Department of Economics, Umeå University \\ SE-901 87 Umeå, Sweden
}

Umeeâ Economic Studies 500, 1999

\begin{abstract}
This paper studies the effect of human capital on the regional entry of firms. An econometric model for a system of disjoint regions and frequency data is constructed, making the comparison between the regions a random discrete choice problem. Empirical evidence from Swedish labour market regions for the manufacturing and the professional service sectors, 1986-1989, is presented. For both sectors, the share with higher education has a positive effect on the regional entry probability of firms in the medium range of the share variable. Sector specific experience has a positive but declining effect on the regional entry probability of firms in the professional service sector whereas it has a negative effect in the manufacturing sector. In relation to other variables in the models the levels of education have moderate effects while the shares with sector specific experience have larger impacts.
\end{abstract}

Key words: Number of Regional Entries, Labour Market Regions, Poisson Regression.

JEL Classification: C23, C25, I21, L0, L1, R12. 


\section{Introduction}

Each region of an economy has general as well as occupation specific human capital embodied in its inhabitants or work force. A region may have a larger stock of human capital than other regions due to initial endowment or because it has attracted highly educated or trained migrants. The stock may also be due to a high level of schooling or on-the-job training in the region. As production and services require qualified labour, the growth of a region may be negatively affected by a shortage of human capital. The aim of this article is to test the effect of human capital on the regional entry of firms for a system of adjacent regions.

Becker (1962) laid the general framework for the individual's investment decision in human capital. More recently, a number of studies has focused on the role of human capital for economic growth (e.g., Romer, 1986, Lucas, 1988). Davidsson et al. (1994) empirically studied possible explanations for the differences in entry rates in Sweden. One of their conclusions is that the population composition and the level of education are correlated with the number of new firms. In a cross-national study, Reynolds et al. (1994) suggested that regional characteristics are major factors affecting variation in new firm formations. ${ }^{1}$ Brewer et al. (1998) showed a positive relationship between intellectual human capital and the founding of firms in the biotechnology sector. At least for this hightech industry the location of intellectual human capital was the principal determinant to the location of the industry itself. ${ }^{2}$

This article attempts to deepen the understanding of the role of human capital for the geographical distribution of organizational founding. By human capital we mean the embedding of resources in people. To fullfil the aim we test the effects of human capital on regional entry by directly modelling the individual firms entry decision. Since data is available at a semi-aggregate level, the final econometric

\footnotetext{
${ }^{1}$ Berglund and Brännäs (1999) estimated non-observable entry and exit flows in Swedish municipalities and found systematic effects of education on mean entry.

${ }^{2}$ Quantified effects of human capital encouraging local economic development are conventionally described in the literature as geographically localized knowledge spillovers.
} 
model explains the number of new firms in a region during a year.

We decompose the profit, that the potential profit maximizing firms envisage in each region, down into its components: revenues, variable and fixed costs. Within this framework, there are two effects on regional entry from an increase in the region's human capital stock. One is an indirect and negative effect via the wage level, and the other is a direct and positive effect through declining variable costs as a result of increasing productivity.

Empirically, we study two sectors, the manufacturing and the professional service sectors and the data we use cover the entry patterns in 80 Swedish labour market regions during the period 1986-1989. ${ }^{3}$ The econometric model recognizes that the dependent variable, entry is a non-negative integer (e.g., Winkelman, 1997).

In Section 2 the problem is formalized for an economy consisting of two regions. This section also provides an extension to include a finite number of disjoint regions. The econometric model is developed in Section 3, which also discusses estimation issues. Section 4 presents the data. The empirical results are given in Section 5, and Section 6 concludes.

\section{Human Capital and Regional Entry}

There are different types of regional entrants among firms, some are the result of innovations, some fulfill a perceived lack of a service or a product in a specific region, and others are the result of lower production costs in the region or specific factor needs.

Viner's (1932) classic investigation of cost curves has permanented the idea that the size and the number of firms in an industry are related to the degree of returns to scale. Krugman's (1991) theory of economic geography extends these ideas. Krugman conceptualizes increasing returns to scale at the level of a spatially distinguishable unit, such as a region. However, returns to scale have their limits.

\footnotetext{
${ }^{3}$ Previous studies (e.g., Davidsson et. al., 1994, 1996, Berglund and Brännäs, 1999) gave reasons to accept that the entry process varies with sector.
} 
There are factors that are not easily duplicated as the firm expands, especially if we consider factors tied to specific locations. Labour is a fairly immobile factor, and it may be expensive to attract employees from other firms and/or locations.

Both individual and regional human capital stocks are unobservable. An individual's stock of human capital changes constantly; it increases with accumulated experience, additional education and decreases as knowledge becomes irrelevant, out dated or forgotten. A region's stock of human capital changes for these reasons as well as through migration, nativity and mortality. The best a potential entrant can do is to make an estimate of each region's human capital stock. We believe that firms ensure that production factors they require are available before locating and that firms carefully study the consequences of different entry locations. So, formalizing this problem, we assume that firms take into consideration regional human capital stocks, when making their locational choice. We will, from now on, concentrate on the effect of two specific components of the region's human capital stock, the share of individuals with higher education and industry specific work experience or specialization.

Consider a profit maximizing potential firm that has decided to enter into a specific sector, and is about to decide on where to locate. The firm has only two alternative locations, region 1 and region 2. Let the revenues from production be $V_{i t}$ and let $C_{i t}$ represent the total cost in region $i$ at time $t$. Define the discounted net profit from the time of entry $t=\tau$ until the known time of exit $t=\epsilon$ in region $i$, as

$$
\pi_{i}=\sum_{t=\tau}^{\epsilon}\left(V_{i t}-C_{i t}\right)(1+r)^{-t}
$$

where $r$ is the interest rate and $(1+r)^{-t}$ is the common discount factor of future revenues and costs.

The firm faces a sequence of regional variables, factor prices and a final price for the product, $p_{i t}$. The fixed entry costs $F_{i}$ are sunk once entry has occurred. We denote the variable cost by $D_{i t}$. The discounted net profit in region $i$ can then be 
written on the alternative form

$$
\pi_{i}=-F_{i}+\sum_{t=\tau}^{\epsilon}\left[p_{i t} q_{i t}-D_{i t}\right](1+r)^{-t}
$$

where $q_{i t}$ is the output level.

Revenues are mainly determined by the local market size and prices. The fixed costs may differ between regions due to differences in start-up cost. The major determinants of the level of variable costs are the factor prices, levels of production and technology. A variable cost function for a sector can be written

$$
D_{i t}=D\left(w_{1 i t}\left(s_{i t}, \bar{s}_{i t}, l_{i t}, \mathbf{v}_{i t}\right), w_{2 i t}, \ldots, w_{b i t}, s_{i t}, l_{i t}\right)
$$

where $w_{k i t}, k=1, \ldots, b$, represents factor prices, $s_{i t}$ is the share of individuals with higher education in the region, $\bar{s}_{i t}$ is the average share with higher education in adjacent regions, and $l_{i t}$ is the share employed in the specific sector. The wage function is defined as $w_{1 i t}\left(s_{i t}, \bar{s}_{i t}, l_{i t}, \mathbf{v}_{i t}\right)$ with $\mathbf{v}_{i t}$ representing a vector of socioeconomic variables.

If we differentiate $D_{i t}$ totally, leaving out the socio-economic variables we get

$$
d D=\frac{\partial D}{\partial w_{1}} d w_{1}+\frac{\partial D}{\partial w_{2}} d w_{2}+\ldots+\frac{\partial D}{\partial w_{b}} d w_{b}+\frac{\partial D}{\partial s} d s+\frac{\partial D}{\partial l} d l
$$

Dividing by the differential $d s$ and assuming the effects of $s$ on $w_{2}, \ldots, w_{b}$ and $l$ equal to be zero we obtain

$$
\frac{d D}{d s}=\frac{\partial D}{\partial w_{1}} \frac{d w_{1}}{d s}+\frac{\partial D}{\partial s}
$$

We can see that there are two effects on regional cost from the share of individuals with higher education. The first effect is an indirect one through the wage. This Mincerian effect is expected to have a positive impact on costs. The second effect is a direct one, interpreted as a productivity effect, and therefore expected to have a negative impact on costs. The same logic holds for $d l$, while the model only contains an indirect effect on regional cost of the educational level of adjacent regions through 
spillover form an increased wage level. ${ }^{4}$ This effect is expected to have a positive impact on costs.

The profit maximizing firm chooses region 1 if the discounted net profit in that region is higher than in region 2 , i.e.

$$
\begin{aligned}
\pi_{1}-\pi_{2} & =F_{2}-F_{1}+\sum_{t=\tau}^{\epsilon}\left[\left(p_{1 t} q_{1 t}-p_{2 t} q_{2 t}\right)-\left(D_{1 t}-D_{2 t}\right)\right](1+r)^{-t} \\
& =-\bar{F}+\bar{V}-\bar{D}>0
\end{aligned}
$$

where $\bar{F}, \bar{V}$, and $\bar{D}$ represent the differences between regions 1 and 2 with regard to fixed costs, discounted revenues and variable costs, respectively. If $F_{1}=F_{2}$, the firm only has to compare post entry revenues and variable costs.

Consider briefly the more general case of one entrant and an existing discrete regional system of $M$ regions. In this case there are profits $\pi_{1}, \ldots, \pi_{M}$ to compare. The firm's choice of region $i$ satisfies $\pi_{i}=\max \left(\pi_{1}, \ldots, \pi_{M}\right)$. Note that the data at hand records the numbers of entries in every region $i=1, \ldots, M$. Therefore, the individual firms' decisions have to be aggregated.

\section{Econometric Model}

In this section, we introduce the econometric model and make clear how it relates to the questions of interest. To construct an econometric model, we introduce additive and random elements into the profit functions thereby making the comparison between the $M$ regions a random discrete choice problem. Let

$$
\Lambda_{i}=\pi_{i}+\varepsilon_{i}=V_{i}-\left(F_{i}+D_{i}\right)+\varepsilon_{i}
$$

where $\pi_{i}$ is expected net profit in region $i$ and $\varepsilon_{i}$ represents a random error observed by the potential entrant but not by the observer. A firm knows its true profit but the observer/researcher does not.

\footnotetext{
${ }^{4}$ Costrell (1994) points out that higher standards and productivity for a single district will not be fully appropriated by its graduates in higher wages. This is because the benefit of higher productivity spills over to the graduates of other districts, who are pooled with them.
} 
Let the net profit associated with the preferred region $i$ be

$$
\Lambda_{i}=\max \left(\Lambda_{1}, \ldots, \Lambda_{M}\right) .
$$

Define the event that a firm $j$ chooses to locate in region $i$ as $u_{i j}=1$, with $u_{i j}=0$ otherwise. The event $u_{i j}=1$ occurs with probability $G_{i}$, and the probability that the firm does not locate in region $i$ is $1-G_{i}$. The probability that region $i$ provides the highest net profit is equivalent to the probability that a firm locates in region $i$. We have for time $t$ :

$$
\operatorname{Pr}\left(\Lambda_{i t}=\max \left(\Lambda_{1 t}, \ldots, \Lambda_{M t}\right)\right) \equiv \operatorname{Pr}\left(u_{i j}=1\right)=G_{i t}=\frac{\exp \left[\pi_{i t}\right]}{\sum_{j=1}^{M} \exp \left[\pi_{j t}\right]},
$$

where the final relationship follows from an assumption of independently and identically, type I extreme-value, distributed $\varepsilon_{i}$ 's (Maddala, 1983, ch. 3).

Next, consider the aggregation of individual decisions to a regional level and assume as above that the locational choices are made independently. The number of entrants in region $i=1, \ldots, M$ at time $t=1, \ldots, T$ can be written

$$
y_{i t}=\sum_{j=1}^{n_{t}} u_{i j t} .
$$

Assume that the number of contemplating or potential entrants, $n_{t}$, is Poisson distributed with parameter $\lambda_{t}=\exp \left(\mathbf{z}_{t} \gamma\right)$, where $\mathbf{z}_{t}$ is a vector of exogenously determined macro variables. It holds that $E\left(n_{t}\right)=\operatorname{Var}\left(n_{t}\right)=\lambda_{t}$.

The resulting Poisson distribution of $y_{i t}$ then has the parameter

$$
\lambda_{t} G_{i t}=\frac{\exp \left(\mathbf{z}_{t} \boldsymbol{\gamma}\right) \exp \left[\pi_{i t}\right]}{\sum_{j=1}^{M} \exp \left[\pi_{i t}\right]}=\frac{\exp \left(\mathbf{z}_{t} \boldsymbol{\gamma}\right) \exp \left[V_{i t}-F_{i t}-D_{i t}\right]}{\sum_{j=1}^{M} \exp \left[V_{i t}-F_{i t}-D_{i t}\right]} .
$$

A related model for a different context has been obtained by Winkelmann (1997, ch. 4).

Before we can proceed to an empirical study we need to give functional forms to the components of (1). In doing this we are faced with making compromises between theoretically well motivated and flexible functional forms and those that are easy 
to estimate from data. As our main focus is on the effects of human capital, this aspect is pronounced more than some other aspects of the specification.

For the revenues, $V_{i t}=p_{i t} q_{i t}$, we assume that the firm is a regional price taker and that the demand function (e.g., Pudney, 1989, ch. 1) is $q_{i t}=f\left(e_{i t}, p_{i t}, \mathbf{b}_{i t}\right)$, where $e_{i t}$ is the average income and $\mathbf{b}_{i t}$ is a vector of variables characterizing region $i$. An increase in the average per capita real income brings about an increase in the demand for the various goods and services of the region. ${ }^{5}$ Let the "demand functions" be linear with constant parameters, i.e. $q_{i t}=\alpha_{0}^{*}+\alpha_{1}^{*} e_{i t}+\alpha_{2}^{*} p_{i t}+\mathbf{b}_{i t} \boldsymbol{\delta}^{*}$. Here, $\alpha_{0}^{*}$ is a constant term, $\alpha_{1}^{*}$ is the effect of income on demand, $\alpha_{2}^{*}$ represents the price effect, and $\delta^{*}$ is a vector of parameters which measures the effect of other regional characteristics.

As is obvious in this, and many other present value calculations, a well-informed entrepreneur or decision maker is presumed. We assume that future variable values equal those of the present, i.e. that the entrepreneur uses a simple forecasting strategy. A consequence of this is that the discount factor $c^{-1}=\sum_{t=\tau}^{\epsilon}(1+r)^{-t}$ is a constant which cannot be separated from other parameters. The equation to replace $\sum_{t=\tau}^{\epsilon} V_{i k}=c V_{i t}$ for region $i$ can then be written

$$
c V_{i t}=c p_{i t} q_{i t}=\alpha_{\mathbf{0}} p_{i t}+\alpha_{1} p_{i t} e_{i t}+\alpha_{2} p_{i t}^{2}+p_{i t} \mathbf{b}_{i t} \boldsymbol{\delta} .
$$

For the fixed entry costs we specify $F_{i t}=\kappa a_{i t}$, where $\kappa$ is a coefficient and $a_{i t}$ represents population density in region $i$ at time $t$.

For region $i$, we specify the following variable cost

$$
c \ln D_{i t}=\rho_{0}+\rho_{1} \ln w_{1 i t}+\ldots+\rho_{b} \ln w_{b i t}+\ln \psi\left(s_{i t}\right)+\ln \xi\left(l_{i t}\right) .
$$

Here, $w_{k i t}$ represents the factor prices. The direct effects on costs from the share of individuals with higher education and the share employed in the sector are operationalized as $\ln \psi(s)=\psi s^{2}$ and $\ln \xi(l)=\xi l^{2}, \psi, \xi<0$.

\footnotetext{
${ }^{5}$ In general the increase in demand is different for different goods and services. It is also different for different sectors.
} 
We use a wage equation that it related to the human capital, earnings function developed by Mincer (1974) to include neighbourhood effects and determinants of the nominal wage in a sector (e.g., Holmlund, 1989). We let the wage be represented by

$$
\ln w_{1 i t}=\theta_{\mathbf{0}}+\theta_{1} s_{i t}+\theta_{2} \bar{s}_{i t}+\theta_{3} l_{i t}+\theta_{4} l_{i t}^{2}+\mathbf{v}_{i t} \boldsymbol{\phi}
$$

Here, $\theta_{1}$ is the return to education in region $i$, while $\theta_{2}$ is the average return to education in neighbouring regions, $\theta_{3}$ provides a measure of sector specific production experience. The concavity of the sector specific production experience is captured by a quadratic experience term, $\theta_{4}$. The vector $\mathbf{v}_{i t}$ includes other variables that affect the wage. The specification in (3) in combination with the linear effects in the wage equation tells us that region $i$ 's productivity increases with the share of individuals with higher education as well as with the share employed in the sector, at a decreasing rate.

The Poisson parameter, $\lambda_{t} G_{i t}$, is obtained by substitution of equations (2), (3) and (4) into equation (1). The log-likelihood function follows directly from the Poisson distribution and the specified mean function $\lambda_{t} G_{i t}$. We have

$$
\begin{aligned}
\ln L & =\sum_{t=1}^{T} \sum_{i=1}^{M}-\lambda_{t} G_{i t}+y_{i t} \ln \lambda_{t} G_{i t} \\
& =\sum_{t=1}^{T} \sum_{i=1}^{M}-\frac{\exp \left(\mathbf{z}_{t} \gamma\right) \exp \left[\pi_{i t}\right]}{\sum_{j=1}^{M} \exp \left[\pi_{j t}\right]}+y_{i t}\left[\mathbf{z}_{t} \gamma+\pi_{i t}-\ln \sum_{j=1}^{M} \exp \left[\pi_{j t}\right]\right]
\end{aligned}
$$

Estimation is performed in the GAUSS package. The covariance matrix is the inverse of the Hessian. An important property of the Poisson distribution is the equality between its mean and variance. If $\operatorname{Var}\left(y_{i t}\right)>E\left(y_{i t}\right)$, there is overdispersion. If detected this has to be accounted for. To account for overdispersion in terms of the covariance matrix for the typical exponential specification an adaptation of results given by Brännäs and Johansson (1996) can be used. There are several possible means of testing against overdispersion. We use a test statistic developed by Cameron and Trivedi (1986) and others. If there is no overdispersion, there is no need to correct the covariance matrix of the Poisson ML estimator. The test statistic 
under the null hypothesis against a more general distribution is

$$
S=\sum_{t=1}^{T} \sum_{i=1}^{M}\left[\left(y_{i t}-\hat{\lambda}_{t} \hat{G}_{i t}\right)^{2}-y_{i t}\right] /\left[2 \sum_{t=1}^{T} \sum_{i=1}^{M}\left[\hat{\lambda}_{t} \hat{G}_{i t}\right]^{2}\right]^{\frac{1}{2}}
$$

The test statistic is one-sided and asymptotically distributed as an $N(0,1)$ variable.

As a measure of goodness of fit we use the deviance $R^{2}$ measure of Cameron and Windmeijer (1996)

$$
R^{2}=\frac{\sum_{t=1}^{T} \sum_{i=1}^{M}\left[y_{i t} \ln \left(\hat{\lambda}_{t} \hat{G}_{i t} / \bar{y}\right)-\left(\hat{\lambda}_{t} \hat{G}_{i t}-\bar{y}\right)\right]}{\sum_{t=1}^{T} \sum_{i=1}^{M} y_{i t} \ln \left(y_{i t} / \bar{y}\right)},
$$

where $\bar{y}$ is the sample mean.

\section{Data and Variables}

We use 80 Swedish labour market regions as our units of analysis. The sample covers the time period 1986-1989 and includes only single plant firms, so that the plant and firm concepts coincide. The dependent variables, entry in the manufacturing and professional service sectors are compiled and previously used by Davidsson et al. (1994). This is also the case for the availability variables approximating the transport and material costs. Other variables that characterize each region are obtained from registers at Statistics Sweden and a county database. ${ }^{6}$ According to Davidsson et al. (1994), the sectorial classification of manufacturing is more certain than the classification of professional services. The data quality also improves over

\footnotetext{
${ }^{6}$ Davidsson et al. (1994) combined three registers at Statistics Sweden. The registers are Centrala företags- och arbetsställeregistret (CFAR), Konsernregistret (KCR), Årliga regionala sysselsättningsregistret (ÅRSYS), and a register for foreign owned firms. The geographical analytical units build on a modification of Statistics Sweden's division of Sweden into 111 labour market regions which reduces the number to 80 . The original division builds on employment commuting over municipal borders. Each region is an independent labour market. The average income, regional average house prices, education and employment data come from register data at Statistics Sweden, while unemployment and regions' geographical size from the Swedish county database. Municipal data is modified to fit the regional system created by Davidsson et al. (1994).
} 
the time period (e.g., Davidsson et al., 1994). Firms operating in more than one sector are classified according to the dominant one, and a reclassification of a firm, if it expands, relocates or changes sector, is made at the beginning of every period. The Swedish Standard Industrial Classification (SE-SIC) utilized matches international classifications. $^{7}$

The overall mean number of entrants in the manufacturing sector is 65 , with standard deviation 123 , while the overall mean in the professional service sector is 134 with standard deviation 383, cf. Table 1. Entry into the manufacturing sector has been relatively constant during 1986-1989 though with a small decline in 1987, see Figure 1. The same decline can also be noticed for the professional service sector, see Figure 2. Concerning the latter, the trough can entirely be assigned to fewer start-ups in the financial sector. For both sectors there is positive skewness in the number of entrants. ${ }^{8}$

The macro variables $\left(\mathbf{z}_{t}\right)$ expected to influence the number of firms contemplating entry are approximated with time specific effects for 1986, 1987 and 1988 and a constant term.

The price level is approximated by using the increase in house prices relative to the 1986 price weighted with the budget share individuals spend on housing, while the share spent on everything else is multiplied by the consumer price index. ${ }^{9}$ Average house prices come from official statistics on municipalities and counties.

Data on average income comes from the income and property register at Statistics Sweden (BE $20 \mathrm{SM}$ ) and is calculated for all individuals that have income and is

\footnotetext{
${ }^{7}$ Manufacturing: High technology (SE-SIC 3522, 3825, 3831, 3832, 3839, 3845, 385), Wood paper and mass (SE-SIC 33, 341), Manufacturing (SE-SIC 38 exclusive high technology), Steel and mining (SE-SIC 2, 36, 37). Other manufacturing (Se-SIC 31, 32, 342, 35 exclusive 3522, 39). Professional services: Knowledge and finance companies (SE-SIC 8321-8325, 83292, 83299, 81, 82, $831)$.

${ }^{8}$ For the years $1986-1989$, skewness is equal to $5.88,5.99,5.49$ and 5.12 for the manufacturing sector, and equal to 6.326 .696 .81 and 6.81 for the professional service sector.

${ }^{9}$ The budget share for housing is 0.25 . The consumer price index series is $100,104,110,117$ with 1986 as the base period.
} 
Table 1: Definitions and descriptive statistics for $M=80$ Swedish labour market regions (Means with standard deviations in parentheses).

\begin{tabular}{|c|c|c|c|c|c|}
\hline Variable & Definition & 1986 & 1987 & 1988 & 1989 \\
\hline $\begin{array}{l}\text { Entry Manu- } \\
\text { facturing }\end{array}$ & Entry for single plant firms & $\begin{array}{r}68.85 \\
(135.18)\end{array}$ & $\begin{array}{r}58.55 \\
(118.73)\end{array}$ & $\begin{array}{r}64.05 \\
(120.08)\end{array}$ & $\begin{array}{r}69.25 \\
(121.18)\end{array}$ \\
\hline $\begin{array}{l}\text { Entry Professional } \\
\text { services }\end{array}$ & Entry for single plant firms & $\begin{array}{r}179.00 \\
(440.80)\end{array}$ & $\begin{array}{r}108.73 \\
(311.53)\end{array}$ & $\begin{array}{r}113.94 \\
(351.10)\end{array}$ & $\begin{array}{r}135.88 \\
(418.85)\end{array}$ \\
\hline Income & Average income $^{a}$ & $\begin{array}{r}78.50 \\
(5.20)\end{array}$ & $\begin{array}{r}81.95 \\
(5.46)\end{array}$ & $\begin{array}{r}85.18 \\
(5.66)\end{array}$ & $\begin{array}{r}89.00 \\
(5.88)\end{array}$ \\
\hline Price & Price index ${ }^{b}$ & $\begin{array}{r}100.00 \\
(0.00)\end{array}$ & $\begin{array}{r}105.57 \\
(1.24)\end{array}$ & $\begin{array}{r}113.87 \\
(2.46)\end{array}$ & $\begin{array}{r}124.28 \\
(3.94)\end{array}$ \\
\hline Population density & Local population aged $16-64 / \mathrm{km}^{2}$ & $\begin{array}{r}22.50 \\
(35.97)\end{array}$ & $\begin{array}{r}22.50 \\
(36.25)\end{array}$ & $\begin{array}{r}22.57 \\
(36.54)\end{array}$ & $\begin{array}{r}22.68 \\
(36.77)\end{array}$ \\
\hline Transport cost & $\begin{array}{l}\text { How large a percentage of the country's } \\
\text { inhabitants in } 1988 \text { are within reach of a } \\
\text { day trip starting from the region's core }\end{array}$ & & & $\begin{array}{r}90.48 \\
(7.73)\end{array}$ & \\
\hline Price material & $\begin{array}{l}\text { How large a percentage of the } \\
\text { country's inhabitants could make } \\
\text { a day trip to the region in } 1988^{c}\end{array}$ & & & $\begin{array}{r}87.89 \\
(11.57)\end{array}$ & \\
\hline Higher education & $\begin{array}{l}\text { Individuals with higher education/ } \\
\text { population aged } 16-64^{c}\end{array}$ & $\begin{array}{r}5.92 \\
(2.02)\end{array}$ & $\begin{array}{r}6.03 \\
(2.06)\end{array}$ & $\begin{array}{r}6.13 \\
(2.11)\end{array}$ & $\begin{array}{r}6.46 \\
(2.24)\end{array}$ \\
\hline Adjacent education & $\begin{array}{l}\text { Higher education in geographically } \\
\text { adjacent regions }{ }^{c}\end{array}$ & $\begin{array}{r}6.98 \\
(1.62)\end{array}$ & $\begin{array}{r}7.13 \\
(1.65)\end{array}$ & $\begin{array}{r}7.26 \\
(1.68)\end{array}$ & $\begin{array}{r}7.68 \\
(1.71)\end{array}$ \\
\hline \multirow[t]{2}{*}{ Experience } & $\begin{array}{l}\text { Individuals employed in the manufactur- } \\
\text { ing sector/total employment }{ }^{c}\end{array}$ & $\begin{array}{r}26.69 \\
(9.86)\end{array}$ & $\begin{array}{r}26.61 \\
(9.89)\end{array}$ & $\begin{array}{r}26.67 \\
(9.83)\end{array}$ & $\begin{array}{r}26.23 \\
(9.63)\end{array}$ \\
\hline & $\begin{array}{l}\text { Individuals employed in the professional } \\
\text { service sector/total employment }{ }^{c}\end{array}$ & $\begin{array}{r}4.44 \\
(1.65)\end{array}$ & $\begin{array}{r}4.72 \\
(1.73)\end{array}$ & $\begin{array}{r}4.87 \\
(1.78)\end{array}$ & $\begin{array}{r}5.33 \\
(1.93)\end{array}$ \\
\hline Unemployment & $\begin{array}{l}\text { Regional unemployment/population } \\
\text { aged } 16-64^{c}\end{array}$ & $\begin{array}{r}3.08 \\
(1.31)\end{array}$ & $\begin{array}{r}2.70 \\
(1.28)\end{array}$ & $\begin{array}{r}2.03 \\
(1.11)\end{array}$ & $\begin{array}{r}1.52 \\
(1.03)\end{array}$ \\
\hline
\end{tabular}

NOTES: ${ }^{a}$ Real mean income in thousands 1986 SEK. ${ }^{b}$ The price index is $0.25^{*}$ house price index $+0.75^{*}$ the consumer price index (base year 1986). ${ }^{c}$ Multiplied by 100. 


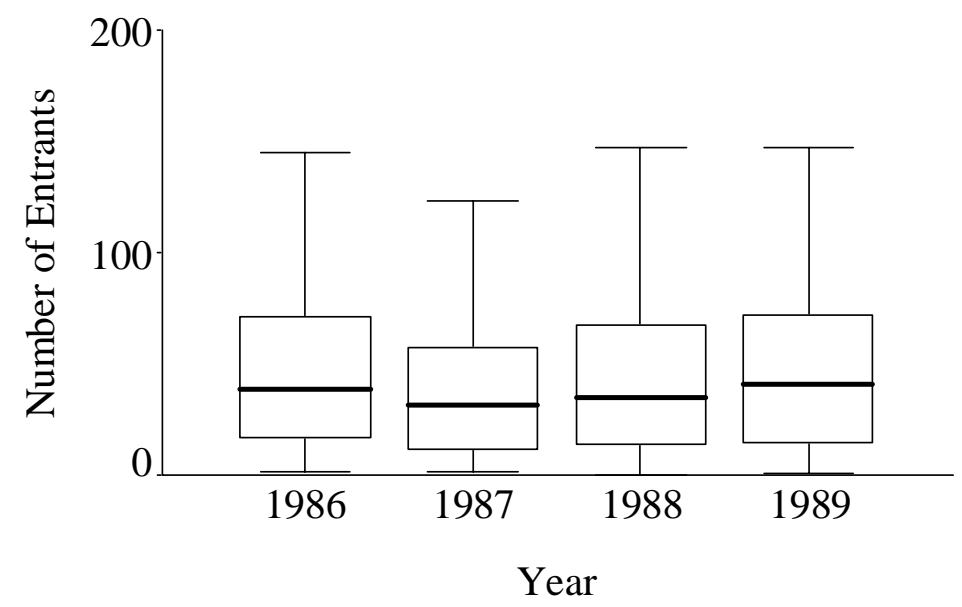

Figure 1: Box-plot of the number of entrants in the manufacturing sector, 1986-1989.

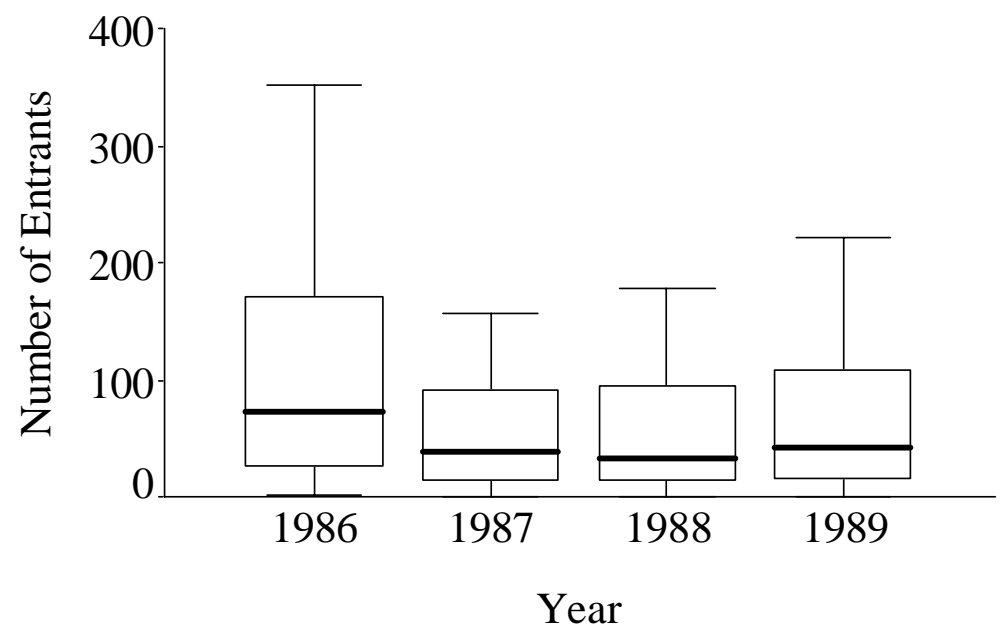

Figure 2: Box-plot of the number of entrants in the professional service sector, 1986-1989. 
the sum of the six income sources: employment, capital, other property, occasional acquisition, landed property or business.

The population density measure is individuals aged 16-64 per square kilometers. We assume that the fixed costs differs between regions because of differences in population density. Usually fixed entry cost is proxied by a linear combination of factors such as market size, growth and concentration. There is also an interpretation of population density so as to provide agglomeration economies in the form of pooled labour markets, technological or information spillover (e.g., Krugman, 1991).

For the manufacturing sector, we see three important factor prices that should be included in the analysis: regional wage $\left(w_{1}\right)$, transport costs $\left(w_{2}\right)$ and the price of material $\left(w_{3}\right)$. For the professional service sector, we only use the wage and transport costs. The two indices that we use as proxies for the transport and material costs need to be explained. ${ }^{10}$ To approximate transport costs, we use an index that measures how large a percentage of the country's inhabitants in 1988 can be reached within one day trip starting from the region's core. We assume that the variable was constant during the whole period. The idea here is that, if the share of individuals within reach is high, the transport costs from this region will be low. To approximate material costs, we us an index that measures how large a proportion of the country's population in 1988 could make a day trip to the region. Here, the intuition is that if the share that could make an over-the-day visit to the region is high, material costs are low due to low transport costs for factors of production.

An individual's return to education and previous work experience are usually measured as years of schooling and length of employment, respectively (e.g., Mincer, 1974). At the regional level, we estimate the effects of education and experience on the regional wage and variable costs using the share that has higher education (university level, three years or longer) and the share employed in the sector, respectively. The variable, higher education in adjacent regions, is created from the education variable by taking the average for all the regions adjacent to a particular

\footnotetext{
${ }^{10}$ These indices were used by Davidsson et al. (1994) to proxy availability.
} 
region. The shares of individuals employed in the manufacturing and professional service sectors match the included SE-SIC codes for entry for manufacturing and professional services.

The indices that we use as proxies for the transport and material costs were strongly correlated, we therefore multiplied them and estimate the effect of the logarithm of the product for the manufacturing sector. This corresponds to employing a restriction $\rho_{2}=\rho_{3}$. The price for introducing the wage level in the manner we do is that the effect of the wage on cost and the effect of the share with higher education on the wage can not be estimated separately. Therefore, we will assume the first effect to be equal to one, i.e. $\rho_{1}=1$. The maximum likelihood routine had difficulties in converging for the most general model specification. Accordingly, we dropped all the variables in the vector $\mathbf{b}_{i t}$ in the demand function and all but unemployment in $\mathbf{v}_{i t}$. We also dropped the constant terms in the variable cost functions and the wage equations (i.e. $\theta_{0}=\rho_{0}=0$ ).

The expression for the profit that we use in the estimation is the following:

$$
\begin{aligned}
\pi_{i t}= & V_{i t}-F_{i t}-D_{i t} \\
= & \alpha_{0} p_{i t}+\alpha_{1} e_{i t} p_{i t}+\alpha_{2} p_{i t}^{2}-\kappa a_{i t}-\exp \left[\theta_{1} s_{i t}+\theta_{2} \bar{s}_{i t}+\theta_{3} l_{i t}\right. \\
& \left.+\phi v_{i t}+\rho_{2} \ln \left(w_{2 i t} w_{3 i t}\right)+\psi s_{i t}^{2}+\left(\xi+\theta_{4}\right) l_{i t}^{2}\right]
\end{aligned}
$$

Note that $w_{3 i t}$ is set equal to one for the professional service sector.

\section{Results}

The test against overdispersion suggests that overdispersion is present, i.e. the conditional variance exceeds the conditional mean. ${ }^{11}$ When overdispersion is present the covariance matrix of the Poisson ML is too small, and has to be corrected. Therefore, the presented standard errors are obtained from a heteroskedasticy-consistent estimator. ${ }^{12}$ The reported deviance $R^{2}$ of Cameron and Windmeijer (1996) suggests

\footnotetext{
$11 S=8.31$ for the manufacturing sector and $S=14.20$ for professional services.

${ }^{12}$ See the GAUSS manual for further information.
} 
an overall good fit for each model.

Table 2 presents the parameter estimates for the models. Note that the estimates are not directly interpretable as signed effects due to the nonlinear forms. In this context the share of individuals with higher education has a positive and significant but decreasing effect on the probability of entry in both sectors. Sector specific experience has a negative and significant but increasing effect on the regional entry probability of firms in the professional service sector whereas it has a negative effect in the manufacturing sector. In both sectors the estimated number of potential entrants decrease over the period.

Further insights can be gained by examining the elasticities for the number of firms of Table 3. These elasticities are calculated as averages based on actual observations for each of the years 1986-1989. Since there are relatively small changes in some of the variables over the time period of the study, some of the elasticities are also relatively constant over time. According to the models, an increase of one percent in the share of individuals with higher education increases the average number of entrants by 0.14 percent in the professional service sector 1987 . In addition, note that an increase of one percent in the share employed in the manufacturing sector decreases the average number of entrants into the sector by about a half percent 1986-1988. Further, an increase in the variable experience in the professional service sector increases the average number of entrants into the sector by more than one percent in the beginning of the period while with 0.69 percent in 1989. Obviously, higher education and work experience matter for a potential entrant's location decision. Elasticities vary across regions. Figure 3 presents elasticities for the average number of firms in the professional service sector 1986-1989 and the share with higher education across labour market regions. When the share with higher education is in the interval 5-10 percent there is a positive effect on the regional entry probability of firms. The negative elasticities are larger for shares below 5 percent than for shares above 10 percent.

The pattern is similar for the manufacturing sector, and for each year. Pictures 
Table 2: Maximum likelihood estimates.

\begin{tabular}{|c|c|c|c|c|}
\hline \multirow[b]{2}{*}{ Variable } & \multicolumn{2}{|c|}{ Manufacturing } & \multicolumn{2}{|c|}{ Professional services } \\
\hline & Estimate & s.e. & Estimate & s.e. \\
\hline Price & 18.99 & $(12.46)$ & 16.48 & $(15.60)$ \\
\hline Income & 0.024 & $(0.01)$ & -0.003 & $(0.01)$ \\
\hline Price squared & -8.454 & $(4.96)$ & -3.617 & $(6.33)$ \\
\hline Population density & -0.004 & $(0.001)$ & -0.007 & $(0.001)$ \\
\hline Transport*Material cost & 0.313 & $(0.15)$ & & \\
\hline Transport cost & & & -0.369 & $(0.56)$ \\
\hline Higher education & 62.23 & $(8.13)$ & 95.19 & $(6.73)$ \\
\hline Higher education $^{2}$ & -717.2 & $(88.16)$ & -1003 & $(66.15)$ \\
\hline Higher education in adjacent regions & -1.473 & $(1.75)$ & -1.358 & $(4.59)$ \\
\hline Experience & -6.615 & $(1.27)$ & -44.53 & $(13.18)$ \\
\hline Experience $^{2}$ & 12.04 & $(2.53)$ & 299.20 & $(90.81)$ \\
\hline Unemployment & 10.38 & $(3.08)$ & -0.455 & $(5.77)$ \\
\hline Time specific effect, $86=1$ & 1.126 & $(0.43)$ & 2.773 & $(0.69)$ \\
\hline Time specific effect, $87=1$ & 0.560 & $(0.29)$ & 1.628 & $(0.45)$ \\
\hline Time specific effect, $88=1$ & 0.244 & $(0.16)$ & 0.788 & $(0.21)$ \\
\hline Constant & 9.548 & $(0.14)$ & 9.776 & $(0.12)$ \\
\hline Sample size & & 320 & & 320 \\
\hline$R^{2}$ & & 0.84 & & 0.92 \\
\hline
\end{tabular}

NOTES: Standard errors in parentheses. Variables previously multiplied by 100 in Table 1 are set to original values during estimation. 
Table 3: Mean elasticities for the number of firms (standard deviations in parentheses).

\begin{tabular}{|c|c|c|c|c|c|c|c|c|}
\hline \multirow[b]{2}{*}{ Variable } & \multicolumn{4}{|c|}{ Manufacturing } & \multicolumn{4}{|c|}{ Professional services } \\
\hline & 1986 & 1987 & 1988 & 1989 & 1986 & 1987 & 1988 & 1989 \\
\hline Price & $\begin{array}{r}2.48 \\
(0.13)\end{array}$ & $\begin{array}{r}1.77 \\
(0.19)\end{array}$ & $\begin{array}{r}0.49 \\
(0.39)\end{array}$ & $\begin{array}{r}-1.42 \\
(0.76)\end{array}$ & $\begin{array}{r}0.13 \\
(0.01)\end{array}$ & $\begin{array}{r}0.19 \\
(0.02)\end{array}$ & $\begin{array}{r}0.20 \\
(0.03)\end{array}$ & $\begin{array}{r}0.07 \\
(0.09)\end{array}$ \\
\hline Income & $\begin{array}{r}-0.72 \\
(0.13)\end{array}$ & $\begin{array}{r}-0.53 \\
(0.15)\end{array}$ & $\begin{array}{r}-0.27 \\
(0.19)\end{array}$ & $\begin{array}{r}0.06 \\
(0.24)\end{array}$ & $\begin{array}{r}0.11 \\
(0.01)\end{array}$ & $\begin{array}{r}0.09 \\
(0.02)\end{array}$ & $\begin{array}{r}0.06 \\
(0.02)\end{array}$ & $\begin{array}{r}0.03 \\
(0.03)\end{array}$ \\
\hline Population density & $\begin{array}{r}-0.26 \\
(0.15)\end{array}$ & $\begin{array}{r}-0.26 \\
(0.15)\end{array}$ & $\begin{array}{r}-0.26 \\
(0.15)\end{array}$ & $\begin{array}{r}-0.26 \\
(0.15)\end{array}$ & $\begin{array}{r}-0.73 \\
(0.26)\end{array}$ & $\begin{array}{r}-0.73 \\
(0.26)\end{array}$ & $\begin{array}{r}-0.73 \\
(0.26)\end{array}$ & $\begin{array}{r}-0.73 \\
(0.26)\end{array}$ \\
\hline Transport cost & $\begin{array}{r}-0.55 \\
(0.44)\end{array}$ & $\begin{array}{r}-0.49 \\
(0.43)\end{array}$ & $\begin{array}{r}-0.41 \\
(0.39)\end{array}$ & $\begin{array}{r}-0.29 \\
(0.38)\end{array}$ & $\begin{array}{r}0.54 \\
(0.36)\end{array}$ & $\begin{array}{r}0.49 \\
(0.34)\end{array}$ & $\begin{array}{r}0.46 \\
(0.34)\end{array}$ & $\begin{array}{r}0.37 \\
(0.32)\end{array}$ \\
\hline Material cost & $\begin{array}{r}-0.55 \\
(0.44)\end{array}$ & $\begin{array}{r}-0.49 \\
(0.43)\end{array}$ & $\begin{array}{l}-0.41 \\
(0.39\end{array}$ & $\begin{array}{r}-0.29 \\
(0.38)\end{array}$ & & & & \\
\hline Higher education & $\begin{array}{r}0.04 \\
(1.34)\end{array}$ & $\begin{array}{r}0.06 \\
(1.29)\end{array}$ & $\begin{array}{r}0.01 \\
(1.20)\end{array}$ & $\begin{array}{r}0.06 \\
(1.17)\end{array}$ & $\begin{array}{r}0.05 \\
(2.04)\end{array}$ & $\begin{array}{r}0.14 \\
(2.00)\end{array}$ & $\begin{array}{r}0.18 \\
(1.97)\end{array}$ & $\begin{array}{r}0.36 \\
(1.91)\end{array}$ \\
\hline $\begin{array}{l}\text { Higher education in } \\
\text { adjacent regions }\end{array}$ & $\begin{array}{r}0.08 \\
(0.07)\end{array}$ & $\begin{array}{r}0.08 \\
(0.07)\end{array}$ & $\begin{array}{r}0.07 \\
(0.07)\end{array}$ & $\begin{array}{r}0.05 \\
(0.07)\end{array}$ & $\begin{array}{r}0.13 \\
(0.09)\end{array}$ & $\begin{array}{r}0.12 \\
(0.08)\end{array}$ & $\begin{array}{r}0.12 \\
(0.08)\end{array}$ & $\begin{array}{r}0.10 \\
(0.09)\end{array}$ \\
\hline Experience & $\begin{array}{r}-0.51 \\
(2.14)\end{array}$ & $\begin{array}{r}-0.49 \\
(2.08)\end{array}$ & $\begin{array}{r}-0.45 \\
(1.81)\end{array}$ & $\begin{array}{r}-0.38 \\
(1.69)\end{array}$ & $\begin{array}{r}1.21 \\
(0.84)\end{array}$ & $\begin{array}{r}1.09 \\
(0.83)\end{array}$ & $\begin{array}{r}1.92 \\
(0.84)\end{array}$ & $\begin{array}{r}0.69 \\
(1.28)\end{array}$ \\
\hline Unemployment & $\begin{array}{r}-0.40 \\
(0.44)\end{array}$ & $\begin{array}{r}-0.31 \\
(0.40)\end{array}$ & $\begin{array}{r}-0.16 \\
(0.30)\end{array}$ & $\begin{array}{r}-0.05 \\
(0.24)\end{array}$ & $\begin{array}{r}0.03 \\
(0.03)\end{array}$ & $\begin{array}{r}0.02 \\
(0.02)\end{array}$ & $\begin{array}{r}0.01 \\
(0.02)\end{array}$ & $\begin{array}{r}0.01 \\
(0.01)\end{array}$ \\
\hline
\end{tabular}




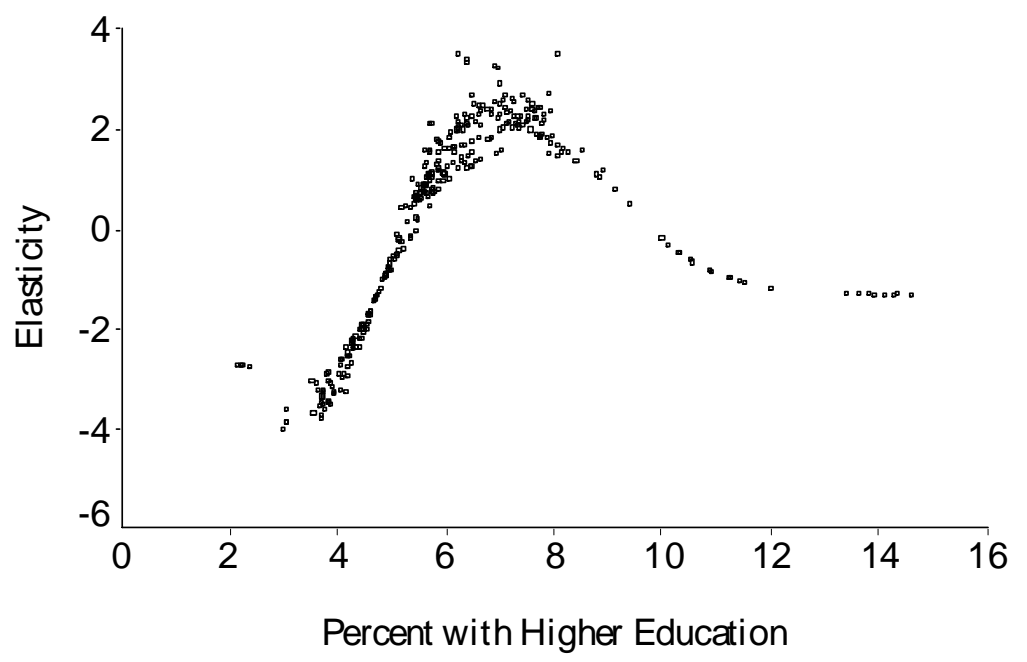

Figure 3: Elasticities for the average number of firms due to a one percent increase in higher education in the professional service sector, 1986-1989, against the percent with higher education.

of sector specific experience reveal positive but declining effects on the regional entry probability of firms in the professional service sector, whereas the effects are negative for the manufacturing sector.

The elasticities of the price index is positive in both sectors 1986-1988, but decline over the period in the manufacturing sector and turn negative in 1989. The transport and material cost elasticities are constant over the period, negative for the manufacturing, whereas positive for the professional service sector. Elasticities of unemployment are negative for the manufacturing sector whereas positive for the professional service sector.

\section{Conclusion}

This paper attempts to measure the impact of human capital on regional number of entries of firms within a model that builds on the two concepts: the number of potential entrants and the entry location decision. In addition to its new approach 
to analyzing regional entry, the study distinguishes itself from earlier studies through its focus on the effects of human capital on regional entry probabilities. Previous studies have used the unemployment rate or a class variable, to proxy the skill or sophistication of the local consumer base. Moreover, they have linked the availability of management skills or skilled labour in an area with the rate of firm exit (e.g., Love, 1996, Berglund and Brännäs, 1999).

The main findings of the paper are, first, for both sectors, when the share with higher education reach a certain lower threshold, the level of education in the region is found to have a positive effect on the regional entry probability of firms. While reaching an upper threshold, the effect is negative. In addition, for both sectors, the education level in adjacent regions are equally or even more important for the probability of entry. Sector specific experience has a positive effect on the regional entry probability of firms in the professional service sector whereas it has a negative effect in the manufacturing sector. Second, in relation to other variables in the models the level of education have a moderate effect while the share with sector specific experience have an important positive impact in the professional service and approximately half as large but in this case negative in the manufacturing sector. Thus, having a pool of individuals with higher education seems to have positive effects on the regional entry probability in both sectors, while a pool of workers with specific expertise only seems important for the professional service sector.

\section{Acknowledgements}

I would like to thank Kurt Brännäs for generous and competent guidance during the work on this article, Per Johansson for his generosity with time in answering questions about Gauss programming and Per Davidsson for providing me with some of the data. Magnus Wikström and Roger Axelsson have commented on earlier versions of the paper and thereby significantly improved the final product. Per-Olov Marklund is thanked for interesting discussions about productivity. 


\section{References}

Becker, G.S. (1962). Investment in Human Capital: A Theoretical Analysis, Journal of Political Economy 70, 9-50.

Berglund, E. and Brännäs, K. (1999). Plant's Entry and Exit in Swedish Municipalities, Umeå Economic Studies 497, Umeå University.

Brännäs, K. and Johansson, P. (1996). Panel Data Regression for Counts, Statistical Papers 37, 191-213.

Brewer, M.B., Darby, M.R. and Zucker, L.G. (1998). Intellectual Human Capital and the Birth of U.S. Biotechnology Enterprises, American Economic Review 88, 290-306.

Cameron, A. C. and Trivedi, P. (1986). Econometric Models Based on Count Data, Comparisons and Applications of some Estimators and Testes, Journal of Applied Econometrics 1, 29-53.

Cameron, A.C. and Windmeijer, F.A.G. (1996). R-squared Measures for Count Data Regression Models with Applications to Health Care Utilization, Journal of Business and Economics Statistics 14, 209-220.

Costrell, R.M. (1994). A Simple Model of Educational Standards, American Economic Review 84, 956-971.

Davidsson, P., Lindmark, L. and Olofsson, C. (1994). Dynamiken i svenskt näringsliv, Studentlitteratur, Lund.

Holmlund, B. (1989). Wage and Employment in Unionized Economies: Theory and Evidence. In Holmlund, B., Löfgren, K.G. and Engström, L. Trade Unions, Employment, and Unemployment Duration. Oxford University Press, Oxford.

Krugman, P.R. (1991). Increasing Returns and Economic Geography, Journal of Political Economy 99, 483-499.

Love, J.H. (1996). Entry and Exit: A County-Level Analysis, Applied Economics 28, 441-451.

Lucas, R. E. (1988). One the Mechanics of Economic Development, Journal of Monetary Economics 22, 3-42. 
Mincer, J. (1974). Schooling, Experience and Earnings, National Bureau of Economic Research, New York.

Maddala, G.S. (1983). Limited-Dependent and Qualitative Variables in Econometrics, Cambridge University Press, Cambridge.

Pudney, S. (1989). Modelling Individual Choice - The Econometrics of Corners, Kinks and Holes, Basil Blackwell, Oxford.

Reynolds, P., Storey, D.J. and Westhead, P. (1994). Cross-National Comparisons of the Variation in New Firm Formation Rates, Regional Studies 28, 443-456.

Romer, P. (1986). Increasing Return and Long-Run Growth, Journal of Political Economy 94, 1002-1037.

Viner, J. (1932). Cost Curves and Supply Curves, Zeitschrift für Nationalökonomie 3, 23-46.

Winkelmann, R. (1997). Econometric Analysis of Count Data, Springer-Verlag, Heidelberg. 